\title{
The Establishment of an Air Defense Identification Zone as an Opportunity in Enforcing the Sovereignty of the State and Law in Indonesia
}

\author{
Harry Purwanto $^{1} \quad$ Levina Yustitianingtyas ${ }^{2}$ \\ 1.Doctorate of Law Faculty, Gadjah Mada University, Yogyakarta, Indonesia and Lecture of Law Faculty, \\ Gadjah Mada University, Yogyakarta, Indonesia \\ 2.Lecture of Law Faculty, Hang Tuah University, Surabaya, Indonesia
}

\begin{abstract}
An Air Defense Identification Zone (ADIZ) is part of a state's air defense system. Within international law, no specific law regulates the state's authority to establish ADIZ nor explicitly prohibits them to set their own ADIZ. Consequently, it is through states own various interpretations of provisions within international law that states have based their authority to determine its ADIZ. Following the practice of other states, Indonesia has also established ADIZ as part of Indonesia's air defense system to enforce the sovereignty of the State and law over airspace. The Indonesian ADIZ is the airspace covering of a small portion of South Sumatra, Java and Madura, Bali, Lombok and a fraction of the western part of Sumbawa Island. A closer look to Indonesia's ADIZ reveals that the zone is still within Indonesia's national territorial airspace. Notably, this is contrary to several states practice in establishing its own ADIZ whose zone is outside its national airspace.
\end{abstract}

DOI: $10.7176 / \mathrm{JLPG} / 85-09$

Publication date:May $31^{\text {st }} 2019$

\section{INTRODUCTION}

\section{A. Background of the Problem}

A state's territory is of significant importance for a number of reasons; among which is that the territory firstly serves as a juridical requirement for the existence of a State in international law; and secondly as a place or marks the boundaries for a State to exercise its sovereignty. Consequently, in essence, a State cannot exercise its sovereignty in areas outside its boundaries, unless that State possesses a sovereign right under international law to do so. In relation to the second reasoning with regard to the importance of a State's territory, specifically in the context of a State's airspace, States have often used its territory to defend its sovereignty, protect its territorial integrity, as well as maintaining the State's integrity. In fact, States have been using bordering airspace as areas to further protect State integrity or to exercise State sovereignty. Several States have established the bordering airspace -outside the State's established territorial airspace- as an airspace identification area or better known as the Air Defense Identification Zone (ADIZ).

The first state to establish their ADIZ was the United States, namely through the establishment of airspace above the Atlantic and Pacific Ocean in 1940. This action was taken by the United States following the Japanese attacks to Pearl Harbor. However, with the force of the 1943 Axis, this no longer became a threat to North America.

The establishment of ADIZ by the United States was followed by other countries, such as Canada, Guam, South Korea, Japan, Russia, Taiwan, and Vietnam. Even China on 23 November 2013, had expanded their air defense zone until it overlapped with South Korea's. The Chinese government recent declaration of their air defense zone required all aircrafts passing East China Sea ask for China's approval. The action that China took sparked reaction from neighboring countries, most particularly Japan. Under this new regulation, all aircraft passing the area must notify their flight plan, their origin, and maintain two-way radio communications to enable them to respond appropriately to China's inquiries. China's air defense zone covers an area nearly the size of England and includes the Senkaku Islands whose ownership is still subject of dispute between China and Japan.

The unilateral action China has taken with regards to its ADIZ has sparked reactions from the current Japanese Prime Minister, Shinzo Abe. According to Abe, China's action is dangerous and can invite an unexpected occurrence. Such concerns was expressed by Abe in front of the Japanese parliament.Strong reactions was also voiced by Japanese allies, the United States. The United States Secretary of State John Kerry has stated he will support Abe should military there be military clashes in the future with regard to the Senkaku Islands. The United States has clearly stated its position on the matter, taking military clashes into calculation.

Indonesia has also established its own ADIZ, which stretches from a portion of the Island of Sumatra and extends above the Islands of Java and Bali and part of the Island of Lombok.

The establishment of ADIZ essentially is the unilateral declaration from a State in order to protect their territorial integrity and sovereignty. The 1944 Chicago Convention on International Civil Aviation does not explicitly state matters in relation to ADIZ. However, it is through the wide interpretation of Article 1"The contracting States recognize that every State has complete and exclusive sovereignty over the airspace above its 
territory"., States perceive that they have authorization to establish an airspace zone in the form of ADIZ. Member States to the 1944 Chicago Convention stated that airspace under its sovereign territory is a closed area, thereby States passed by foreign aircrafts may force those aircrafts to report their identities, for reasons of State protection and security. In connection with that, will be discussed: 1). How would States establish its ADIZ in view of obtaining recognition from other States and at the same time having its establishment to be in accordance with international law ?, and 2). What is the possibility of enforcing state sovereignty through the establishment of ADIZ, from the perspective of the enforcement of state sovereignty and the law in Indonesia through airspace ?

The purpose and odjective of this discussion are: 1). To determine measures that must be made in establishing ADIZ so as to not come into conflict with international law and to obtain recognition from other States. 2). To gain an in-depth insight into the possibility of enforcing state sovereignty through the establishment of ADIZ seen from the perspective of such enforcement in Indonesian airspace.

\section{LEGAL MATERIAL AND METHODS}

This research is a normative legal research that related to the establishment of an Air Defense Identification Zone as an opportunity in enforcing the sovereignty of the state and. Legal materials used are primary legal materials, secondary legal materials, and tertiary materials, while the approach used is a statute approach, and a case approach. Legal materials are collected in two ways, namely the study of documents and literature studies related to the establishment of an Air Defense Identification Zone as an opportunity in enforcing the sovereignty of the state and law in Indonesia. Case approach the research method used in the preparation of this writing is a normative juridical method. Normative juridical research is research that refers to legal norms contained in international regulations or related national conventions and regulations.

\section{RESULT AND DISCUSSION \\ THE ESTABLISHMENT OF AIR DEFENSE ZONES IN THE PERSPECTIVE ON AIR DEFENSE IN INDONESIA}

\section{A. Air Defense Identification Zone in the International Law Framework}

\section{The Nature of ADIZ in the System of Air Defense}

Air defense zone is airspace where states may exercise control over the use of such area in the interest of protecting territorial and state integrity. Essentially, states may only exercise its sovereignty within its territory. In Law of the Sea, State sovereign rights over a specific territory in the sea is recognized (Article33, 55, and 76,United Nations Convention on the Law of the Sea 1982)., the same does not apply to airspace. In airspace law, State sovereign rights over airspace is not recognized (Article 1, 1944 Chicago Convention). One form of State efforts in protecting territorial and state integrity is through the establishment of the Air Defense Identification Zone ("ADIZ"). The establishment of ADIZ by several States have not been within its airspace, but covers also the territory bordering its airspace, outside its own territory. According to "A Dictionary of Law", an 'Air Defense Identification Zone' is a zone, which can extend in some cases up to 300 miles beyond the territorial sea, established for security reasons by some states off their coasts. When entering ADIZ, all aircrafts are required to identify themselves, report flight plans, and inform ground control of their exact position (A Dictionary of Law :Online Version 2012). In general, ADIZ extends from a State's territory until the airspace above the high seas bordering that state. Every State may form an ADIZ within airspace under its sovereignty extending up to airspace over the high seas. ADIZ was formed based on security considerations, particularly the need to identify aircrafts entering a State's ADIZ (MarkasBesar A.B.R.I. 1986:p.30). All aircrafts entering this zone and flying towards the State's land are required to report their flight plan. The effectiveness of ADIZ can be achieved if it is supported by the Air Traffic Control (ATC) system, which could take actions in correlation with the national air defense system (Mabes ABRI TNI-AU : p. 30, Yasidi Hambali , 1994 : p.7).

ADIZ was established as a supporting facility in the national air defense system in identifying aircrafts detected through Air-Defense radar. The main objective of the State in establishing ADIZ, which may at times extend over high seas, is to increase national security. This is done by identifying all aircrafts approaching the airspace above a State's national airspace in accordance to the conditions set by the state who established the ADIZ ((Mabes ABRI TNI-AU : p. 147). This understanding is in line with the opinions of RuwantissaAbeyrante and Major SusMirtusin. According to RuwantissaAbeyrante, the objective in establishing ADIZ is to properly identify all approaching aircraft for security purposes so that they could, prior to entry into national airspace, satisfy certain local entry requirements (RuwantissaAbeyrante, 2012:p. 11-12). Whilst according to Mirtusin, the establishment of ADIZ is formed based on considerations on security, particularly the need to identify aircrafts approaching a State's ADIZ. Furthermore, Mirtusin stated that the establishment of ADIZ is not in view of extending the sovereignty of that State over the high seas as covered under that State's ADIZ (img.dilmil.bandung.go.id/uploud/adiz ind.yt.pdf).

\section{States Legal Basis in Establishing ADIZ}

No international law provisions regulate explicitly on the establishment of ADIZ by a State. Consequently, in 
establishing ADIZ, States have seemingly tried to search for legal basis to support their actions. It is through interpretations and analogies that States found useful legal basis in establishing ADIZ.

First isthrough Article 1 of the 1944 Chicago Convention; "The contracting States recognize that every State has complete and exclusive sovereignty over the airspace above its territory". Through a wide interpretation of the Article, States feel they have the authorization to establish ADIZ. Additionally, States view airspace under its sovereign territory as a closed area, thereby States passed by foreign aircrafts may force those aircrafts to report their identities, for reasons of State protection and security. Although the Chicago Convention does not explicitly regulate the establishment of ADIZ, a document issued by ICAO, Document 9426-AN/924 First Edition 1984 ICAO (International Civil Aviation Organization), in Chapter 3 on 'Airspace Organization' Paragraph 3.3.4 on 'Special Designated Airspace', recognizes the existence of a State's ADIZ.

Second, is the precautionary principle (Ruwantissa Abeyratne, 2011:p.13). In the event no empirical or scientific evidence exists, this should not prevent a State in preventing attacks or dangers before it occurs in order to protect state assets. The precautionary principle (which is a moral and political concept) states that in the event where identified potentially dangerous effects from a particular process or phenomenon and where scientific evaluation does not guarantee that the risk could be averted, the burden of proof falls to the persons to advise on the particular action (Ruwantissa Abeyratne, 2011:p.13).

Third is Cooper's Control Theory. According to Cooper, State sovereignty over airspace is determined by the ability of the concerned States to control the airspace above its territory. Cooper further stated that: "[...] in the absence of international agreement, that the territory of every state extends upward as far into space as it is physically and scientifically possible for any one state to control the regions of space directly above it" (Priyatna Abdurrasyid, 2003 : p.103). This theory is used by the United States in establishing their ADIZ.

Fourth is the reasoning behind the establishment of an Air Defense Identification Zone (ADIZ) and how it is formed as a supporting facility in the national defense system of a State. Based on this reasoning, the establishment of ADIZ finds its basis under the principle of self-defense recognized under Article 51 of the United Nations Charter "Nothing in the present Charter shall impair the inherent right of individual or collective self defense if an armed attack occurs against a Member of the United Nations, until the Security Council has taken measures necessary to maintain international peace and security. Measures taken by Members in the exercise of this right of self-defence shall be immediately reported to the Security Council and shall not in any way affect the authority and responsibility of the Security Council under the present Charter to take anytime such action as it deems necessary in order to maintain or restore international peace and security."

The right of self-defense within the Charter is an inherent right. The provision within Article 51 exists not only to create a right but explicitly recognizes the existence of the right to self-defense within the principles of International Law. A State's right to defend itself from outside forces (other States) has become part of customary international law (Malcolm N. Shaw QC, 2005 :p. 1035). This Article is often associated with the right to limited use of force. As noted by Higgins, the UN Charter has given a limited scope in using use of force when exercising the right to self-defense both as an individual and as a collective. Additionally, international law scholars and state practice have also interpreted the right to self-defense through broadly interpreting self-defense into selfpreservation. Bowett for example stated that Article 51 can be interpreted as a non-restricting right to self-defense. Bowett opined that there is no relationship between an armed attack and the right to self-defense. No state can afford to wait until an armed attack occurs to finally exercise their right to self-defense (http://www.scribd.com/doc/49232153/Bag-3-Isi.).

Fifth, another the legal basis underlying the establishment of ADIZ is that it is an international practice which has become part of customary international law. Article 38 (1) of the Statute of the International Court of Justice states customary international law as a recognized source of law. Customary law derives from the practice of States through the behavior and actions taken by them for a particular issue. If a State undertakes a certain policy and that policy is followed by other States with repeated practice and is absent any protest or challenge from other States, the States who follow such practice have done so due to a belief that such actions was carried out by states due to a legal obligation.

\section{State Practice in the Establishment of ADIZ}

National security considerations have prompted coastal States to perform identification measures toward approaching foreign aircrafts (before the aircrafts enter the States' territory). These identifying measures can even extend as much as several hundred miles outside its territorial borders. Consequently, even if these aircrafts are over the high seas and are subject to the exclusive jurisdiction of their origin States, a number of coastal States have claimed the right to exercise control toward foreign aircrafts outside their territorial airspace through those coastal States' ADIZ (Nicholas Grief, 1994 : p. 146-147).

Coopers Control Theory was used as the basis for ADIZ's establishment by the United States on December 1950 over the airspace above the Atlantic and Pacific Ocean during the Korean War, with the outbreak of World War II, the United States in 1940 reinforced control over airspace above the coasts, this became very important 
after the Pearl Harbor attack by Japan. With the outbreak of the Korean WAR, the United States put its Air Force on alert and conducted coordination with internal defense units. The air defense systems and its control structure developed in 1950, lead to the five Air Defense Identification Zones around North Amerika. If radio communications proved to be unsuccessful in an ADIZ, the Air Force would send interceptor planes to visually identify to intruder aircraft. The United States established ADIZ formally within its Code of Federal Regulations: 14 CFR Part 99. The CFR emphasized United States' ADIZ as an area of airspace over land or water in which the ready identification, location, and control of civil aircraft is required in the interest of national security. The United States' ADIZ above the Atlantic extends until 200 miles from the United States' national coastline. Furthermore, 14 CFR Part 99.49 states that all airspace of the United States is designated as Defense Area, whereby aircraft control is required in the interest of national security. Thereby, ADIZ forms a transition zone where aircrafts enter a territory identified and controlled by both air traffic controls and defense authorities (Nicholas Grief, 1994, : p.148).

The United States has focused its air-defense system on areas of airspace holding an important role due to the presence of a vital object or the area being the 'centre of gravity' in the country. The centralization of several air defense systems must consider also the correlation between the use of that airspace and the user of that airspace wherever they might come from. Thereby the United States, with its airspace coverage abilities, could use a variety of the ADIZ infrastructures to identify and take action against aircrafts which poses threats to vital objects and also achieve Air Supremacy in that area. Thus, the main concept to the establishment of ADIZ is to protect vital objects within United States, namely the country's centre of government in that area. The United States have five ADIZ outside its territorial sea, namely: a) ADIZ located above Altantic Ocean extending 300 NM. b). ADIZ located south of California extending up to 400 NM. c). ADIZ located in Alaska extending 350 NM above Bering Sea d). ADIZ around Guam extending 250 NM. e). ADIZ in Hawaii extending 250 NM (Nicholas Grief, 1994 : p. 148).

In general, information required in an ADIZ are: 1). Aircraft call sign. 2). Number and type of aircraft. 3). Altitude (within ADIZ) 4). True Airspeed 5). Time of Departure. 6). Point of Departure. 7). Destination. 8). Transponder code, an estimated pointwhen entering ADIZ which shows the aircraft's position in latitude/longitude or Fix-Radial-Distance.

Five months later, Canada issued a number of regulations entitled "Rules for the Security Control of Air Traffic". Similar to the United States, the regulations issued by Canada was formulated for the purpose for Canada's interests in its national security, identification, and controls over aircrafts operation in its territory under "Canadian Air Defense Identification Zones" or CADIZ. (Hugh Kindred : p. 402)

The position of CADIZ extends to 300 NM from Canada's North, East, and a portion of its West borders outside of Canada's territory as a filter against various forms of air threat from those directions. The establishment of those air defense zone was done in consideration of the development of Canada's strategic environment, particularly the Primary Defense Weapon System potential of other States, in this case the threat is the resurgence of Russia's nuclear weapons capable of achieving Canada's vital state objects. Information required in CADIZ are:1). Aircraft call sign, 2). Number and type of aircraft, 3). Altitude (within CADIZ), 4). True Airspeed, 5).Time of Departure, 6).Point of Departure, 7).Destination, 8). Transponder code, estimated point when entering CADIZ which could show the aircraft's position in latitude/longitude or fix-radial distance.

Then the end of 2013, on 23 November 2013, the People's Republic of China, established ADIZ above the East China Sea. The reason China gave in establishing this ADIZ was to defend its state sovereignty and security of its territorial airspace, maintain aviation order, and as an effective exercise of China's right to self-defense. By invoking ADIZ, China demands that all aircraft (commercial, military, or others)must inform their intentions to Chinese authorities and adhere to the aviation rules or face severe measures. Every aircraft must inform their flight plan to authorized Chinese officials, maintain two-way radio communications, and keep the radar transponder activated. However, China's establishment of its ADIZ sparked controversy between China and a number of states, such as Japan, South Korea, and Australia. The controversy was caused among others by: 1).China's ADIZ establishment overlapped with Japan and South Korea's ADIZ; 2). China's ADIZ covers currently disputed areas namely the Senkaku or Diaoyu Islands; 3). The purpose of China's ADIZ was not for the sole purpose of national security interests, but to occupy the Senkaku or Diaoyu Islands; 4). Was not negotiated with neighboring countries; 5).Is discriminative and provocative in character. Below is China's ADIZ: 


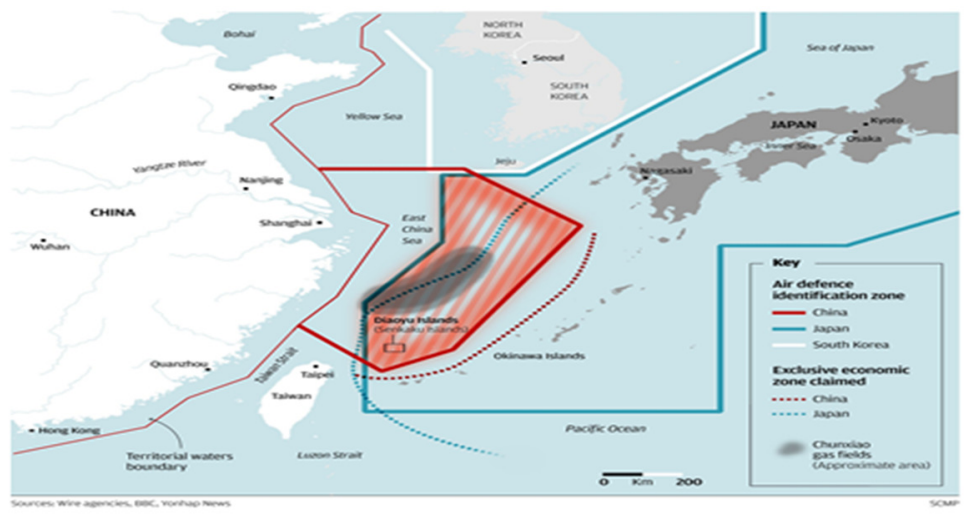

B. ADIZ as an enforcement tool for state sovereignty and law, within Indonesia's Air Defense System 1. The philosophical and constitutional foundations of Air Defense

The Indonesian people declared their independence on 17 August 1945, and henceforth shall defend their independence, as well as the sovereignty of the state and its people, based on the Pancasilaand the 1945 Constitution. The vision of the Indonesian people on state defense may be found in the Preamble and Body of the 1945 Constitution:

1) Freedom is actually a right of all nations and therefore colonization in this world must be removed as it contravenes the humanity and justice;

2) The government of the State of Indonesia that protects all Indonesian people and the entire land of Indonesia and to develop the welfare of the people, the life of the nation, and participate in the world orderliness based on freedom, eternal peace and social justice (Paragraph 4, Pre amble of the 1945 Constitution of the Republic of Indonesia).

3) Each national shall be entitled to and participate in state defense; (Article 27 para (3) to be read with Article 30 para (1) 1945 Constitution of the Republic of Indonesia)

4) Soil and water and natural wealth contained therein shall be controlled by the state and used for the welfare of the people to the utmost (Article 33 para (3) 1945 Constitution of the Republic of Indonesia).

Based on Indonesia's worldview as above, Indonesians carry out national defense based on the principles of:

1) The Indonesian people shall be entitled to and participate in defending the independence and sovereignty of the state, territorial integrity and the safety of the entire people from all threats;

2) State defense carried out with the participation of the people in national defense is the responsibility and privilege of all Indonesian nationals. Not one national may evade the obligation in state defense, unless otherwise regulated by law. Within this idea, there exists an understanding that state defense must be based on each national's consciousness of their rights and obligations, and in their own power;

3) The Indonesian people love peace, but place greater importance in independence and sovereignty. Dispute settlement or conflicts which may exist between Indonesia and other states shall always be settled through peaceful means. Indonesia sees war as a last resort, only when all peaceful efforts have failed. This principle embodies Indonesia's view on war and peace;

4) Indonesia rejects all forms of colonization and adopts the free-active political worldview. External national defense is active-defensive, which means refraining from an aggressive role and rejecting expansion so long as national interests are not threatened. Hence, Indonesia is not tied to or a participant in defense pacts with other states;

5) National defense is universal and involves the entire people, national resources, infrastructure and superstructure, as well as the territory of Indonesia.

6) National defense is based on democracy, human rights, general prosperity, environment; national law, international law and customary international law, as well as the principle of peaceful coexistence, taking into account Indonesia's archipelagic geography. In addition, national defense also considers the principles of independence, sovereignty and social justice.

Based on Indonesia's worldview, national defense is aimed at securing Indonesia's sovereignty and territorial integrity. State sovereignty is a political and legal element of a state's international legal personality; therefore the Indonesian government aims to preserve this through a 'universal defense' (otherwise known as 'total war' [Ed.]). This involves all components available to the state such as its nationals, territory and resources. These components are pre-prepared by the government and used in an integrated, coordinated and sustained manner. The primary component in national defense is the Indonesian Armed Forces (TentaraNasional Indonesian); they are complemented with reserve and support components. 
Indonesia's will for national defense have spawned a number of national legislation, especially those concerning airspace. These are Act No. 3 of 2002 and Act No. 34 of 2008, supplemented by additional regulations such as Act No. 43 of 2008 and Act No. 1 of 2009.

Article 6 of Act No. 3 of 2002 on National Defense states that national defense is done through the development of the state's ability to resist and respond to threats. National defense aims to preserve and protect sovereignty and territorial integrity over national airspace, to preserve Indonesia's unity and the safety of its people from threats. Generally, Act No. 3 of 2002 lays out 5 chains of national defense. First, the government lays out the General Policy on National Defense. Second, this General Policy is implemented by the Minister or Defense by drafting a National Defense Implementing Policy and General Policy on the Use of The Indonesian Armed Forces. Third, the Department of Defense - as the implementing agency- has the authority to draft the development of the state's defense forces and draft general policies on the use of defense components. Fourth, the Commander-inchief of the Indonesian Armed Forces (Panglima TNI) utilizes the state's political policies on national defense as guidelines to draft military strategies. Fifth, the drafting and implementation of national defense policy is periodically overseen by the House of Representatives.

As follow up to Act No. 3 of 2002, Act No. 34 of 2004 on the Indonesian Armed Forces was issued. This new Act emphasized that the Indonesian Armed Forces acted as Indonesia's defense tool, to carry out national defense to preserve state sovereignty and territorial integrity, protect the Indonesian people, carry out military operations within and outside of wars, and actively participate in regional peace and security. Article 10 of this Armed Forces Act states that the Indonesian Air Force is tasked with upholding the law and preserving security in Indonesia's national jurisdiction in accordance with national and ratified international law. The Indonesian Air Force carries out development of air power and the utilization of air defense territories.

The Indonesian Air Force is given the authority and obligation in enforcing state sovereignty and law in airspace,including restricted airspace, limited airspace and dangerous airspace in accordance with its primary function. In its implementation, Air Defense Operations comprises of active and passive air defense. Active defense involves detection, identification and action. Consider the last two cases concerning violation of Indonesian airspace, and the Bawean case of 2003. In the first case, on 22 October 2014 at around 11.30 East Indonesia Standard Time, 2 Sukhoifighter jets of the Indonesian Air Force from Command Sector II Makassar, forced an Australian civilian propeller driven airplane to land at Sam Ratulangi Air Force airbase in Manado. In the second case, on 28 October 2014, Sukhoifighter jets of the Indonesian Air Force forced another foreign airplane to land. The second case involved a Singaporean civil airplane, a Beechcraft 9L with tail number VH-PFK, which was intercepted by 2 Sukhoi27/30 Flankers above the South China Sea. The suspicious airplane was flying in Indonesian territory without permit at a height of 20-25 thousand feet at 250-350 knots. In the Bawean case, regardless of the existence of a permit, the United States has not recognized or ratified the United Nations Convention on the Law of the Sea 1982 which Indonesia has ratified through Act No. 17 of 1985 and followed up by Act No. 6 of 1996- which recognizes that sovereignty in the air and sea are separate matters. The ratification of UNCLOS is especially relevant to the archipelagic sea lanes which are regulated by the Indonesian government via Government Regulation No. 37 of 2002 which contains provisions on Indonesian Archipelagic Sea Lanes ( $A L K I$ ), which are set out in $A L K I I, I I$ and $I I I$, to emphasize Indonesia's status as an archipelagic state.

The interception incidents above show several notable points in air defense and air sovereignty:

1) Based on the principle of sovereignty in the air, Indonesia may order and force a landing of foreign aircraft flying unauthorized in Indonesian airspace;

2) To enforce state sovereignty through air power, the Indonesian Air Force acts as the main stakeholder and is assisted by other elements of the Indonesian Armed Forces;

3) Airplanes used in interception are certain types of jet fighter, in this case Sukhoifighter jets.

4) The success of Active Air Defense is supported by cooperation between military and civilian radars, in additional to the human resources and condition of interceptors.

5) Aerial incidents are usually dealt with through political and diplomatic processes, as opposed to legal proceedings.

Passive air defense encompasses: a) aerial threat observations, and b) remediation of the effects of air attacks.

The law complements and emphasizes the air defense system in Acts No. 43 of 2008 and No. 1 of 2009.

Based on Act No. 43 of 2008 on National Territory, Indonesia is an archipelagic island with sovereignty over its territory, and has sovereign rights to be used for the greatest benefit of the Indonesian people. Territory encompasses land, inland waters, archipelagic waters and territorial waters including the sea bed and airspace above it; and includes all the natural resources contain within it. The aim of regulating state territory is to guarantee territorial integrity, state sovereignty and order in border regions.

Article 5 of Act No. 1 of 2009 on Aviation states that Indonesia has full and exclusive sovereignty over Indonesian airspace. To carry out this sovereignty, the government has authority and the responsibility to regulate airspace for the benefit of aviation, national economy, national defense and security, socio-cultural and the airspace itself. 


\section{Duties in the Enforcement of Sovereignty and Law}

Sovereignty is an important attribute to the existence of State as legal person under international law. Therefore, for States keep its relevance as a legal person under international law, it will constantly strive to defend its sovereignty. The role of sovereignty have been regarded as important as a State attribute in conducting relations in the international community, as seen through the acceptance of the principle of respect towards a state's sovereignty. The implementation of Sovereignty and Law within a state will carry on as routine unless intruded upon by other parties. Should an intrusion happen over the sovereignty and law of a State, then enforcement measure will be needed. It is through these enforcement measures that the sovereignty and law of a State will become more apparent. In its relation to State integrity, the enforcement of state sovereignty and law is the raison d'etre of national defense.

The enforcement of state sovereignty through national airspace covers the notion enforcement of the law in accordance to applicable law and through the concerned authorities. The enforcement of state sovereignty here is aimed specifically toward national security interests in airspace. Law enforcement, as elaborated above can be conducted in two ways, namely by growing legal awareness or through threat or coercion. Further, in law enforcement, three elements must be taken into consideration: legal certainty, utility and justice. In law enforcement, there must be a compromise between those three elements. The three elements must be proportionally balanced; however doing so is not easy in practice (Sudikno Mertokusumo, 1991:p.1-2)

Law enforcement in Indonesian national airspace is an activity conducted in resolving breaches in national airspace. Besides the three elements, attention must also be paid toward the means of enforcement. From the two means stated above in breaches within Indonesia's national airspace, then the first enforcement measure (growing awareness) must be conducted first and foremost. If the first means proves unsuccessful, then the second measure may be exercised afterwards (threat or coercion). In sum, if a breach occurs in territorial airspace, for example if an aircraft entered Indonesia's national airspace without permit then Indonesia has the right to take responsive actions toward the aircraft. Such measures may be mild or severe. Mild responsive actions for example are notifications to the aircraft's radio communication to land at the nearest airport or to leave the Indonesian airspace entirely, whilst severe responsive actions can be exercised by forcing an aircraft to land through escorting it to the nearest airport. In fact, military aircraft that do not heed such orders may be shot down. However, responsive actions towards civil aircrafts must not resort to the use of weapons and heed the provision within the Appendix to Annex 2 (Rules of the Air) to the Convention on International Civil Aviation.

The duty to enforce sovereignty in airspace, including its law enforcement, is conducted by the Indonesian Air Force in accordance to the authority given under law, both national and international. Furthermore, under Article 10 letter b of Act No. 34 of 2004 on Indonesian National Armed Forces, it is stated that the duty of the Air Force are:

a. To carry out the duties of the National Air Force in the field of defense.

b. To enforce the the law and maintain the security of airspace within national jurisdiction in accordance to national laws and ratified international laws.

c. To carry out the duty of the National Armed Forces in the construction and development of air power; as well as

d. To carry out the empowerment of the air defense area.

The above duties are in line with the duties of the Indonesian National Armed Forces in general as Indonesia's tool of defense where Indonesian Air Force serves as a unit alongside other units namely the Army and the Navy. As emphasized under Article 10 paragraph (3) of Act No. 3 of 2002 on State Defense, the Indonesian National Armed Forces have the duty to carry out state defense for the purposes of:

a. To defend state sovereignty and territorial integrity.

b. To protect state honor and its salvation.

c. To conduct military operations other than war.

d. To actively participate in the duty in regional and international peace-keeping.

3. The Establishment of Indonesia's ADIZ; A Dilemmatic Effort in the Air Defense System

\section{a. Indonesian airspace}

Indonesia is an archipelagic state. The term 'archipelagic states' is recognized under the 1982 Convention on the Law of the Sea. Indonesian territory comprise of areas of land, sea and air. Indonesia's total area including its land and water (EEZ included) covers approximately 7.7 million $\mathrm{km}^{2}$ with land covering 1,9 million $\mathrm{km}^{2}$, and sea covering 5,8 million $\mathrm{km}^{2}$. While Indonesia's territorial airspace is the space above the land and sea under Indonesia's sovereignty. The areas of sea under Indonesia's sovereignty including the space above it, includes the inland sea, territorial sea and archipelagic waters (Article 2 par. (2), article 49 par (2) UNCLOS 1982). State Sovereignty over airspace is governed under the 1944 Chicago Convention, which states that, "the contracting States recognize that every State has complete and exclusive sovereignty over the airspace above its territory". The airspace entirely subjects itself to the complete and exclusive sovereignty of the subjacent state. Consequently, international law does not recognize the right of innocent passage for foreign aircraft of any kind in a State's 
national airspace (http://www.icao.int/secretariat/legal/List\%20of\%20Parties/Chicago_EN.pdf).

In Indonesia, state sovereignty in airspace is regulated under Article 5 Act No. 1 of 2009 concerning Aviation stating that Indonesia has full and exclusive sovereignty over its airspace. State sovereignty and territorial integrity, including airspace, must be protected as mandated under Article 5 paragraph (1) Act No. 43 of 2008 concerning State Territory. Spatial planning for airspace have not entirely attempted to further aspects in national security interests as priority is given more so to aviation safety. Consequently, Indonesia spatial planning on airspace has not been able to optimally support the duty of the Air Force. One aspect to airspace planning in relation to national air defense is the establishment of ADIZ as an identification zone requiring civil and military aircrafts to report its flight plans. The legal basis to the establishment of ADIZ is the international practice which has gained customary international law status (MarkasBesar TNI AU, 2000 : p.8).

\section{b. The establishment of Indonesia's ADIZ}

Indonesia is a large archipelagic state. Covering an area of $3.200 .000 \mathrm{~km} 2$ with five large islands namely Sumatera, Java, Kalimantan, Sulawesi, and Irian. Indonesian airspace extends from Sabang to Merauke. Geographically, Indonesia is positioned between two continents (Asia and Australia) and two oceans (Pacific and Indian Ocean). This position makes Indonesia, especially its airspace, a strategic area for foreign aircraft to pass from one state/Continent to another state/Continent. In the context of aviation, in an effort for a State to control an airspace for the protection of state integrity as well as its assets, an air defense identification zone or ADIZ may be established.

In air defense, it is not enough to discuss only of jet fighters, air defense radars, and medium and long range missiles, because included in a nation's air defense is ADIZ, an identification zone for air defense that a sovereign nation such as Indonesia must have. This relates closely to issued flight routes above Indonesian Archipelagic Sea Lanes, where foreign aircrafts have the right to fly over Indonesian Archipelagic Sea Lanes without obtaining Indonesia's prior permission. This condition will surely create vulnerabilities if there is no control over territorial airspace. In the event Indonesia establishes an Indonesian ADIZ (IADIZ) it must not contradict with the practice of the international community through its international treaties, customary international law (K.Martono, 2012:p. 5), as well general legal theories. In relation to the establishment of IADIZ, Regulation issued by the Commander to the National Air Defense No.: Perpang/04/IX/2010 established the IADIZ covering airspace above the Islands of Java, Bali, and the surrounding islands. See picture below (http://angkasasena.blogspot.com/2008/05/airdefence-identification-zone-adiz.html).

Picture : Indonesian Air Defense Identification Zone

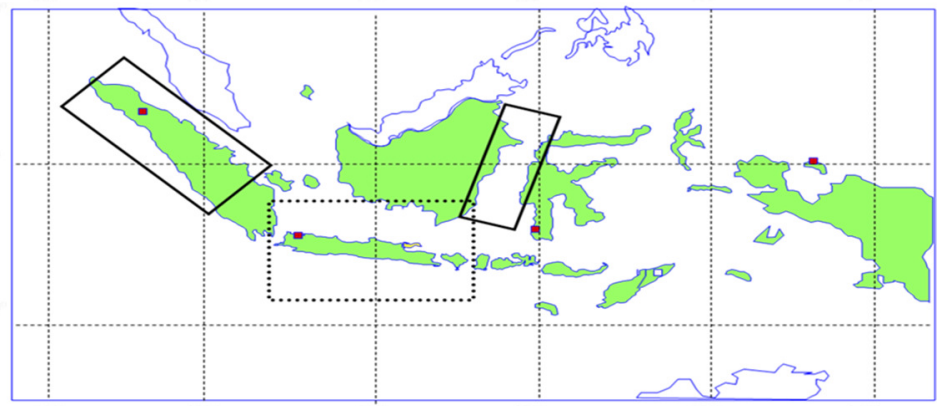

Source: http://angkasasena.blogspot.com/2008/05/air-defence-identification-zone-adiz.html

The dotted line forming the rectangle in the map of Indonesia above is an illustration of ADIZ as regulated under Regulation issued by the Commander to the National Air Defense No.: Perpang/04/IX/2010, The Indonesian ADIZ geographically is airspace located above land and sea extending from $95^{\circ} 00^{\prime} \mathrm{E}$ to $141^{\circ} 00^{\prime} \mathrm{W}$, and $6^{\circ} 00 \mathrm{~N}$ to $11^{\circ} 00^{\prime} \mathrm{S}$. With these measurements, Indonesia's airspace is illustrated as a very large dimension of space $\left(5,193,252 \mathrm{~km}^{2}\right)$ In Indonesia's sovereign territory, Indonesia has established its own ADIZ. The Indonesian ADIZ is based on Aeronautical information publication Volume 1 dated 17 September 2006 and located at $040000 \mathrm{~S}$ 10400 00E 0400 00S. 11700 00E 1000 00S 11700 00E 1000 00S 10400 00E 0400 00S 104 00 00S. Whereas the solid lines on the map represents the establishment of IADIZ in the future. The Indonesian ADIZ is located in the airspace above a small part of South Sumatera, Java, Madura, Bali Lombok, and a small part of west of Sumbawa. The Indonesian government's consideration in establishing ADIZ was for the purpose of protecting vital state interests, such as the state house as a state symbol, HalimPerdanaKusuma air force base, Iswahyudi air force base, Madiun, air force base at Surabaya's Indonesian naval base. Legal basis used by the Indonesian government in establishing IADIZ is the state right to self-defense manifested in the State Defense System. Every State has the inherent right to self-defense. This right is recognized by international law, most especially by Article 51 of the United Nations Charter. If we closely examine Indonesia's ADIZ, the zone is not located outside its national territorial airspace, therefore as a zone for identifying aircraft approaching national airspace, the zone 
cannot function optimally. Control over airspace is an absolute necessity for the viability of the State. Breaches/violations in national airspace still occur. According to data from the end of 2009 until the beginning of 2011, 14 violations occurred in national airspace. These airspace violations, especially by foreign military aircrafts, can create vulnerability as it becomes a threat to vital national objects Mayor Sus Mirtusin, (img.dilmil.bandung.go.id/uploud/adiz ind.yt.pdf).

The current Indonesian ADIZ covers only Java and its surroundings, however if we compare the land area to the sea, the Island of Java is less than 1/8 of total territorial area under Indonesia's sovereignty. Whilst ideally, for a State as large as Indonesia with the largest archipelago in the world, Indonesia's air defense strength should include all areas within it territory from its west corner until its east. Therefore, there is a need to develop nearlyideal air defense zones by adding two areas of ADIZ as seen in the Indonesian map above represented by the thick lines forming a rectangular shape, located above North Sumatera and between Kalimanatan and Sulawesi.

According to Captain Teddy HambrataAzmir, for an ideal IADIZ created for the purpose of covering all Indonesian airspace, a system of layered zones is needed, namely:

a) Domestic ADIZ, an air defense identification zone covering all Indonesian borders.

b) Coastline ADIZ, an ADIZ covering air defense along Indonesia's coastlines..

c) ADIZ for Land-to-Air Defense, an air defense identification zone above metropolitan areas as well as above centre of government and economic hubs. The zone can be activated and deactivated at any time according to applicable NOTAM or Notice to Airmen(restrictedand prohibitedarea) (http://lembagakeris.net/2012/06/zona-identifikasi-pertahanan-udara-indonesia).

Based on the establishment of IADIZ above and further connecting it to its future additions, a number of weaknesses or flaws can be found:

a) Even though ADIZ has gained recognition through Article 51 of the United Nations Charter and customary international law, it has yet to gain support in the national legal system. This can be seen from the provisions within Act No. 43 of 2008 on State Territory, Act No. 1 of 2009 on Aviation and also regulations associated with the rights and obligation of foreign sea vessels and aircrafts implementing the Right of Passage through Archipelagic Sea Lanes under Government Regulation No. 37 of 2002. A further examination of these laws shows that they do not regulate matters on ADIZ.

b) A closer look into the position of the current ADIZ (and also the future), shows that itis flawed as it covers only a portion of national airspace. This is different to the practice of other states in the positioning of their ADIZ, namely placing the zone outside its territorial borders. The Indonesian ADIZ is not in line with the raison d'etrebehind the establishment of ADIZ that is as a tool for early identification for aircrafts before they enter national airspace. Air defense identification zones should be outside national territorial airspace so aircrafts can report their flight plans before they enter national airspace and states can identify them early on.

c) The presence of IADIZ in relation to Air Traffic Control (ATC). ATC has an important contribution in air services to support IADIZ. This will be problematic if the ATC is under the authority of the FIR (flight information region) belongs to another state.

d) The Indonesian ADIZ may become problematic when connected to the establishment of Indonesian Archipelagic Sea Lanes. This relates to the Rights and Obligations of Foreign Aircrafts in exercising the Right of Passage above the Indonesian Archipelagic Sea Lanes as governed under Government Regulation No. 37 of 2002. The Indonesian Archipelagic Sea Lanes (ASL) which covers the Sunda Strait as well as the Lombok Strait overlaps with the Indonesian ADIZ over a small portion of South Sumatera, Java and Madura, Bali, Lombok, and small portion of Sumbawa. Problems emerge when aircrafts who use the overlapping corridor do not report the flight plans or identify themselves before entering Indonesian airspace as required in ADIZ zones but not in ASL zones.

With the shortcomings of the system as discussed above, moreso when connected to the established Indonesian ASL, it would be wise for the Indonesian to re-examine the establishment of Indonesian ADIZ.

\section{CONCLUSIONS AND SUGGESTIONS}

A. Conclusions

Based on the discussion above, it can be concluded as follows:

1. That no international law prohibits States from establishing ADIZ for national security interests. However, the establishment of ADIZ must consider the interest of neighboring countries or countries in general, to avoid protests by those states. The implementation of provisions on ADIZ must also be conducted in a nondiscriminatory manner.

2. The establishment of ADIZ in airspace bordering Indonesia's territorial airspace can actually be used as a bid in enforcing sovereignty of the state and law in Indonesian airspace. However, currently, Indonesian ADIZ extends only above Java, Bali and a portion of Sumatera and Kalimantan, making the enforcement of state sovereignty and the law less than optimal. The Indonesian Government in establishing its ADIZ in 
airspace bordering territorial airspace must consider also the right of passage of foreign aircrafts above Indonesian Archipelagic Sea Lanes.

\section{B. Suggestions}

As an archipelagic state, in establishing ADIZ Indonesia must consider applicable international law that applies to Indonesia as a state party, one of which is the 1982 UNCLOS. When Indonesia became a state party to this Convention it required Indonesia to establish its Archipelagic Sea Lanes, and Indonesia has done so. If the establishment of IADIZ is located outside and borders Indonesian national airspace, then this will interfere with foreign aircrafts entering Indonesian national airspace.

\section{REFERENCES}

Chappy Hakim, 2011, Pertahanan Indonesia, AngkatanPerang Negara Kepulauan, Red \& White Publishing. Publishing.

Dempsey, 2005, Annals of Air and Space Law, Vol. XXX Part.1, The Carswell, Company, Toronto Canada.

Eddy Suyanto, MarekalMuda TNI, 2011, PengaturanPenggunaanRuangUdara (SuatuTanggungJawab Negara TerhadapKeamanandanKeselamatanPenerbangan), Paper Seminar, FakultasHukum UNDIP

Forum Strategi TNI-AL, 1991, PenetapandanPengaturan Sea Lanes sebagaiTindaklanjut UU RI No. 17 tahun 1985 tentangPengesahanKonvensi PBB tentangHukumLaut, Paper Seminar, Jakarta,

GülSangül, 2004, The Evolving Concept of Sovereignty in Air Law, McGill University, Faculty of Law Institute of Air \& Space Law, Montreal

IgnMaryanto, 2003, KonsepsiPenataanRuangUdara FIR Indonesia DalamRangkaMendukungTugas TNI AU padaMasamendatang, KertasKerjaPeroranganSastra Jaya, SekolahStafdanKomando TNI AU

Kay Hailbronner, Freedom of The Air and Convention on The law of The Sea, AJIL, Vol.77, No.3 July, 1983.

Michael Milde, 1983,UNCLOS - Possible Implication for International Air Law, annals of Air and Space Law, By IcaslMc Gill University Montreal Canada, Vol. VIII.

MochtarKusumatmadja, 2003, PengantarHukumInternasional, Binacipta Bandung

P. de VreisLentsch, The right of Overflight Over Strait States and Archipelagic States : Developments and Prospects, Netherlands Yearbook of International Law, vo. XIV, 1983

Petter A. Dutton, "Petter A. Dutton,'CaelumLiberam: Air Defense Identification Zones Outside Sovereign Airspace", The American Journal of International Law, Vol. 103 No.4

PriyatnaAbdurrasjid, 2003, Kedaulatan Negara di Ruangudara, Jakarta,

RuwantissaAbeyratne, 2011, In Research of Theoritical Justification for Air Defence Identification Zones, Springer Science Business Media, LCC

SatjiptoRahardjo, 2009, PenegakanHukum, SuatuTinjauanSosiologis, Genta Publishing, Yogyakarta.

SudiknoMertokusumo, 1991, PenegakanHukumdanPenemuanHukum, Paper bahanPenataran, Yogyakarta

TentaraNasional Indonesia, 2006, Dasar-DasarHukumUdarabagiPelaksanaanOperasiUdara AngkatanUdara,MarkasBesarAngkatanUdara, Jakarta

, A Dictionary of Law, 2011, Jonathan Law, Elizabeth A Martin Publisher: Oxford University Press. Print Publication date, 2009.

\section{Indonesian National Legislations}

Undang-UndangDasar Negara Republik Indonesia 1945,

UndangUndangNomor 6 Tahun 1996 tentangPerairan, Lembaran Negara Republik Indonesia Tahun 1996 Nomor 73, tambahanLembaran Negara Republik Indonesia Nomor 2994.

UndangUndangNomor 3 Tahun 2002 TentangPertahanan Negara, yang di sahkanpadatanggal 8 Januari 2002 , Lembaran Negara Republik Indonesia, TambahanLembaran Negara republik Indonesia Nomor 4169

UndangUndangNomor 34 Tahun 2004 TentangTentaraNasional Indonesia, yang di sahkanpadatanggal 6 Oktober 2004, Lembaran Negara Republik Indonesia Tahun 2004 Nomor 127, TambahanLembaran Negara republik Indonesia Nomor 4439.

Undang-UndangNomor 43 Tahun 2008 tentang Wilayah Negara, Lembaran Negara RepublikndonesiaTahun 2008 Nomor 177, TambahanLembaran Negara Republik Indonesia Nomor 4925.

Undang-UndangNomor 1 Tahun 2009 tentang Wilayah Negara, Lembaran Negara RepublikndonesiaTahun 2009 Nomor 1, TambahanLembaran Negara Republik Indonesia Nomor 4956

\section{International Treaties}

Chicago Convention on International Civil Aviation, Signed at Chicago, on 7 Desember 1944.

United Nations Convention on the Law of the Sea (UNCLOS), Done at Montego Bay, December, 10, 1982, entry into force, November, 15, 1994 


\section{Internet}

Mayor SusMirtusin, img.dilmil.bandung.go.id/uploud/adiz ind.yt.pdf.

http://angkasasena.blogspot.com/2008/05/air-defence-identification-zone-adiz.html.,accessed 21 September 2014

Kapten Pnb Teddy HambrataAzmir, http://lembagakeris.net/2012/06/zona-identifikasi-pertahanan-udaraindonesia/, Accessed 21 September 2014

http://en.wikipedia.org/wiki/Air_Defense_Identification_Zone_\%28North_America\%29, Accessed 21 September 2014 